\title{
MANAJEMEN KURIKULUM BERBASIS ENTREPRENEURSHIP DI SMA MUHAMMADIYAH 9 SURABAYA
}

\author{
Muhammad Dandi Subiantoro \\ Jurusan Manajemen Pendidikan, Fakultas Ilmu Pendidikan, Universitas Negeri Surabaya \\ Email: dandijaya.reygen@gmail.com \\ Karwanto \\ Jurusan Manajemen Pendidikan, Fakultas Ilmu Pendidikan, Universitas Negeri Surabaya \\ Email: karin_haidar@yahoo.com
}

\begin{abstract}
Abstrak
Penelitian ini bertujuan untuk mengetahui dan menganalisis: (1) Perencanaan kurikulum berbasis entrepreneurship di SMA Muhammadiyah 9 Surabaya, (2) Pelaksanaan kurikulum berbasis entrepreneurship di SMA Muhammadiyah 9 Surabaya, dan (3) Evaluasi kurikulum berbasis entrepreneurship di SMA Muhammadiyah 9 Surabaya. Penelitian ini menggunakan pendekatan kualitatif deskriptif dengan metode studi kasus. Teknik pengumpulan data dilakukan dengan cara observasi, wawancara, dan studi dokumentasi. Analisis data yang digunakan adalah analisis deskriptif kualitatif dengan memberikan pemaparan gambaran mengenai situasi yang diteliti dalam bentuk uraian naratif mulai dari tahap pengumpulan data, reduksi data, penyajian data, dan penegasan kesimpulan. Uji keabsahan data dilakukan dengan menggunakan triangulasi sumber data, triangulasi teknik, dan member check. Hasil penelitian dilapangan dapat dijelaskan sebagai berikut. (1) Perencanaan kurikulum berbasis entrepreneurship dimulai dengan menentukan struktur kurikulum yang akan menjadi dasarnya, setelah terbentuk struktur mulai dipikirkan konsep struktur tersebut yang terdiri dari latar belakang, tujuan, ruang lingkup, standar kompetensi, dan kompetensi dasar yang nantinya akan mengatur proses pembelajaran di SMA Muhammadiyah 9 Surabaya. (2) Pelaksanaan kurikulum berbasis entrepreneurship mempunyai pengaturan yang berjenjang pada setiap tingkatan kelas peserta didik sesuai dokumen kurikulum yang telah disusun, setiap proses pembelajarannya selalu diintegrasikan dengan aspek entrepreneurship dan beberapa ada yang menghasilkan produk sebagai capaian hasil belajar. (3) Evaluasi dilakukan dengan berpedoman pada sasaran mutu sekolah dan memperhatikan dimensi program dan pelaksanaan.
\end{abstract}

Kata Kunci: manajemen kurikulum, kurikulum berbasis entrepreneurship

\section{PENDAHULUAN}

$\begin{array}{rccc}\text { Sumber } & \text { daya } & \text { manusia } & \text { yang } \\ \text { berpendidikan } & \text { adalah } & \text { modal } & \text { utama } \\ \text { pembangunan } & \text { nasional, } & \text { terutama } & \text { dalam }\end{array}$ bidang perekonomian bangsa. Artinya, semakin banyak SDM yang berpendidikan pada suatu negara maka semakin mudah pula untuk mensukseskan pembangunan nasional. Akan tetapi, SDM yang dihasilkan pun harus bisa menjadi leader dalam segala bidang dan siap menghadapi tantangan yang ada.Tujuan pendidikan bukan hanya untuk memperoleh ijazah atau gelar bagi kepentingan pribadi. Sesuai dengan pembukaan Undang-Undang Dasar 1945 bahwa tujuan pendidikan adalah mencerdaskan kehidupan bangsa. Oleh karenanya, negara harus selalu memajukan elemen pendidikan dalam aspek kehidupan untuk menghasilkan SDM yang berkualitas dan kompetitif.

Setidaknya ada tiga alasan utama dari beberapa banyak alasan mengapa pendidikan harus diletakkan pada bagian yang fundamental dalam suatu bangsa. Pertama, menurut Undang-Undang Nomor 20 Tahun 2003 tentang SISDIKNAS tertuang pendidikan nasional berfungsi mengembangkan kemampuan dan membentuk watak serta peradaban bangsa yang bermartabat dalam rangka mencerdaskan kehidupan bangsa. Kedua, berdasarkan Undang-Undang Nomor 2 tahun 1989 menyatakan. Pendidikan nasional bertujuan untuk mencerdaskan kehidupan bangsa dan mengembangkan manusia Indonesia seutuhnya, yaitu manusia yang beriman dan 
bertaqwa terhadap Tuhan YME dan berbudi pekerti luhur, memiliki pengetahuan dan keterampilan, kesehatan jasmani dan rohani, berkepribadian yang mantap dan mandiri serta rasa tanggung jawab kemasyarakatan dan kebangsaan. Ketiga, Fungsi pendidikan dalam TAP MPRS Nomor XXVI/MPRS/1966 tentang Agama, pendidikan dan kebudayaan, bahwa tujuan pendidikan adalah untuk membentuk manusia Pancasila sejati berdasarkan pembukaan Undang Undang Dasar 1945.

Berdasarkan fungsi diatas harusnya pemerintah lebih memberdayakan pendidikan baik dari segi sistem, strategi, input, serta outputnya sebagai pencapaian kesempurnaan substansi pendidikan. Pada pemberdayaan substansi pendidikan inilah diharapkan tercapainya SDM yang berkualitas, adaptif, serta generatif dalam mengatasi berbagai permasalahan yang begitu kompleks dimasa depan. Salah satu masalah pokok dalam masyarakat modern yang menjadi pekerjaan rumah bagi pemerintah adalah pengangguran. Saat ini pengangguran adalah masalah yang cukup serius terjadi di Indonesia, kondisi ini diperparah dengan kebijakan yang selalu berhenti ditengah jalan dalam menyelesaikan masalah pengangguran ini. Pengangguran merupakan masalah kompleks yang memberi dampak buruk pada kehidupan. Hal ini karena tingkat pengangguran yang tinggi mengakibatkan banyak SDM tidak terpakai, sehingga menyebabkan pendapatan masyarakat lemah. Situasi ini menimbulkan kelesuan ekonomi yang berpengaruh pula pada emosi masyarakat serta kehidupan keluarga sehari- hari, dengan kata lain maraknya pengangguran meningkatkan tindak kriminal, kemiskinan, kemerosotan tingkat kesehatan, kesenjangan sosial, dan lain sebagainya.

Berdasarkan laporan BPS (Badan Pusat Statistik) dalam (www.bps.go.id) menyatakan jumlah angkatan kerja Indonesia pada Februari 2015 sebanyak 128,3 juta orang, bertambah sebanyak 6,4 juta orang dibanding Agustus 2014 atau bertambah sebanyak 3,0 juta orang dibanding Februari 2014. Penduduk bekerja pada Februari 2015 sebanyak 120,8 juta orang, bertambah 6,2 juta orang dibanding keadaan Agustus 2014 atau bertambah 2,7 juta orang dibanding keadaan Februari 2014. Tingkat Pengangguran Terbuka (TPT) Februari 2015 mencapai sebesar 5,81 persen, mayoritas pengangguran merupakan angkatan kerja terdidik lulusan sekolah menengah atas dan kejuruan, laju peningkatan angka pengangguran lulusan Universtas berada ditingkat kedua setelah SMA/SMK.

Sebenarnya persoalan pengangguran di Indonesia tidak terlepas dari seberapa besar peran pendidikan dalam mencetak lulusan yang umumnya lebih cenderung diarahkan untuk menjadi pencari kerja dari pada menciptakan lapangan kerja. Padahal ketimpangan antara ketersedian lapangan kerja dengan pencari kerja sangat tidak seimbang. Entrepreneurship atau biasa disebut kewirausahaan yang menjadi bahan perbincangan akhir-akhir ini banyak diyakini sebagai problem solving dalam mengatasi permasalahan yang dialami masyarakat Indonesia, terutama dalam hal mengentaskan kemiskinan. Oleh karenanya penelitian ini dianggap penting karena entrepreneur mempunyai banyak manfaat dalam pembangunan ekonomi suatu bangsa. Kasmir (2008:65) menyatakan, "entrepreneur adalah orang yang berjiwa berani mengambil resiko untuk membuka usaha dalam berbagai kesempatan". Berjiwa berani mengambil resiko artinya bermental mandiri dan berani memulai usaha, tanpa diliputi rasa takut atau cemas sekalipun dalam kondisi tidak pasti. Pendidikan kewirausahaan atau entrepreneurship merupakan kajian internasional terkini yang terus diteliti dan dikembangkan secara dinamis diseluruh belahan dunia.

Maraknya program entrepreneurship atau biasa disebut pendidikan kewirausahaan diseluruh dunia ini tidak lain karena semakin meningkatnya kesadaran akan pentingnya karakter kewirausahaan pada generasi muda 
(kreatif, inovatif, berani mengelola resiko) dan pentingnnya kedudukan seorang entrepreneur pada suatu motor pergerakan perekonomian suatu negara. David McClelland (Frinces, 2011:4) bahwa "salah satu syarat suatu negara untuk mencapai tingkat kemakmuran diperlukan $2 \%$ dari jumlah penduduknya adalah entrepreneur (wirausaha)". Sementara Menteri Koperasi dan UKM Anak Agung Gede Ngurah Puspayoga dalam (www.republika.co.id`Koran, 2015) menyatakan bahwa jumlah pengusaha di Indonesia hanya sekitar 1,65 persen dari jumlah penduduk saat ini. "Kita kalah jauh dibandingkan dengan negara tetangga. Misalnya Singapura sebesar 7 persen, Malaysia 5 persen, dan Thailand 4 persen". Berdasarkan pernyataan diatas, negara ini perlu mempertajam minat dan motivasi jiwa entrepreneur pada setiap warganya. Jiwa entrepreneurship harus ditanam sejak anak masih duduk dibangku sekolah, oleh karenanya paradigma seorang entrepreneur perlu ditumbuhkembangkan melalui proses pembelajaran dilembaga sekolah yang ada di Indonesia. Disinilah tujuan inti kewirausahaan/entrepreneurship dimasukkan dalam dunia pendidikan.

Menjawab persoalan di atas SMA Muhammadiyah 9 Surabaya sebagai lembaga pendidikan memadukan kurikulum yang berlaku nasional dengan tambahan mengenai entrepreneurship dan kemampuan spiritual dengan corak islam muhammadiyah semenjak sekolah itu baru diresmikan tahun 2011. SMA Muhammadiyah 9 Surabaya adalah lembaga pendidikan islam yang berbasis entrepreneurship, hadir di tengah- tengah masyarakat untuk membantu mewujudkan generasi-generasi yang mandiri, siap berwirausaha dengan berwawasan IPTEK dan IMTAQ. Visi dari SMA Muhammadiyah 9 Surabaya adalah mewujudkan lembaga islam yang berbasis entrepreneur dengan aplikasi multimedia, bilingual, dan character building. SMA Muhammadiyah 9 Surabaya menerapakan 8 (delapan) standar nasional pendidikan sesuai dengan aturan dari Dinas
Pendidikan Dasar dan Menengah dengan dimuati dua standar tambahan yaitu Alislam dan muhammadiyah.

Sebagai bentuk pelaksanaan dari kurikulum berbasis entrepreneurship ini lahirlah suatu ide tentang pilar-pilar yang harus dikembangkan di SMA Muhammadiyah 9 Surabaya. Pertama, dengan bahasa entrepreneur sekolah rutin mendatangkan pebisnis sukses untuk menularkan ilmunya kepada anak-anak dan membuat mereka tertarik untuk kesana, pameran produk entrepreneur setiap akhir semester, on the job training (OJT) atau magang, pendidikan luar kelas (kunjungan industri) setiap akhir semester. Selain dari beberapa program unggulan tersebut, dalam menunjang keefektifan kurikulum berbasis entrepreneurship di SMA Muhammadiyah 9 Surabaya juga ada suatu kegiatan ekstrakurikuler dengan nama entrepreneur club yang diwajibkan bagi seluruh siswa untuk mengikutinya. Kedua, perancangan kurikulum berbasis entrepreneurship. Perancangan tersebut terdiri dari pengembangan sikap dan perilaku wirausaha, kepemimpinan dan perilaku prestatif, solusi masalah ekonomi, pembuatan keputusan, pelatihan sikap terampil, kreatif, dan inovatif dalam pengembangan jiwa wirausaha, tanggap terhadap peluang bisnis, dan pelatihan untuk mengembangkan bisnis secara syar'i.

Kurikulum berbasis entrepreneurship di SMA Muhammadiyah 9 Surabaya adalah kurikulum nasional yang diperkaya dengan pendidikan entrepreneurship (kewirausahaan) karena konsep pendidikan nasional terbuka untuk pengayaan. Hal ini sesuai dengan Undang-Undang No 20 tahun 2003 tentang SISDIKNAS dan Peraturan Pemerintah No 19 tahun 2005 tentang standar pendidikan nasional yang memberikan banyak ruang bagi lembaga pendidikan untuk membuat dan mengelola kurikulumnya sesuai dengan tensi dan kompetensi wilayah atau lingkungan yang dimilikinya. Kesempatan ini hendaknya dapat dimanfaatkan juga oleh 
setiap sekolah atau pihak pemerintah setempat untuk menciptakan sebuah lembaga pendidikan yang lebih terarah, cakap, dan terampil.

Kurikulum berbasis entrepreneurship ini diharapkan dapat membekali peserta didik keterampilan soft skill dan hard skill berwirausaha dengan cara memasukkan muatan kewirausahaan baik secara substansi nilai-nilai kewirausahaan maupun aplikasinya pada setiap proses pembelajaran. Hal ini berkaitan erat dengan kurikulum yang disusun dalam sekolah guna menjawab masalah peningkatan kualitas sumber daya manusia untuk bisa bersaing diera global. Selain itu Kurikulum berbasis entrepreneurship ini juga diharapkan dapat menjadi kurikulum kunci yang akan menjadi ukuran keberhasilan sekolah menciptakan lulusan yang berdaya saing tinggi dipasar kerja sehingga keluaran dari pendidikan Indonesia mampu menjadi solution maker untuk bangsanya, bukan problem maker. Oleh karena itu peneliti tertarik dalam mengambil judul terkait "Manajemen Kurikulum Berbasis Entrepreneurship di SMA Muhammadiyah 9 Surabaya" yang telah menanamkan dan menghasilkan output dari nilai kewirausahaan sebagaimana telah diterapkan.

Berdasarkan uraian yang dikemukakan di atas, fokus penelitian ini mengenai manajemen kurikulum berbasis entrepreneurship di SMA Muhammadiyah 9 Surabaya. Selanjutnya dari fokus tersebut dirinci menjadi 3 (tiga) subfokus yaitu, sebagai berikut:

1. Perencanaan berbasis entrepreneurship di SMA Muhammadiyah 9 Surabaya.

2. Pelaksanaan kurikulum berbasis entrepreneurship di SMA

Muhammadiyah 9 Surabaya.

3. Evaluasi kurikulum berbasis entrepreneurship di SMA

Muhammadiyah 9 Surabaya.

\section{METODE}

Penelitian ini menggunakan metode deskriptif analitis dengan pendekatan kualitatif serta rancangan studi kasus. Sumber data utama dalam penelitian ini ialah kata-kata dan tindakan, selebihnya adalah data tambahan dokumen dan lain-lain. Kata-kata dan tindakan orang yang dapat diamati di lingkungan SMA Muhammadiyah 9 Surabaya yaitu: kepala sekolah, wakil kepala sekolah, kepala urusan (KAUR) dan, guru. Sumber data utama dicatat melalui catatan tertulis, dengan menggunakan perekam suara melalui handphone, dan pengambilan gambar dengan kamera. Teknik pengumpulan data dalam penelitian ini dilakukan dengan empat cara, yaitu: observasi, wawancara semiterstruktur, dan studi dokumentasi. Uji keabsahan data pada penelitian ini meliputi credibility (validitas internal) dengan cara triangulasi teknik dan sumber, transverbility (validitas eksternal), dependability (reliabilitas) dan conformability (obyektifitas) melalui member check. Penelitian ini juga menggunakan teknik analisis data melalui pengumpulan data (Data Collection), reduksi Data (Data Reduction), penyajian Data (Display Data), serta verifikasi dan Penegasan Kesimpulan (Conclution Drawing and Verification). Tahapan penelitian ini adalah tahap pra lapangan, pekerjaan lapangan, analisis data, dan evaluasi serta pelaporan.

\section{HASIL DAN PEMBAHASAN}

Berikut penjelasan temuan penelitian dan pembahasan mengenai Manajemen Kurikulum Berbasis Entrepreneurship di SMA Muhammadiyah 9 Surabaya dengan subfokus penelitian: (1) Perencanaan kurikulum berbasis entrepreneurship di SMA Muhammadiyah 9 Surabaya; (2) Pelaksanaan kurikulum berbasis entrepreneurship di SMA Muhammadiyah 9 Surabaya; (3) Evaluasi kurikulum berbasis entrepreneurship di SMA Muhammadiyah 9 Surabaya dapat dijelaskan sebagai berikut. 
1. Perencanaan

Kurikulum

Berbasis Entrepreneurship di SMA Muhammadiyah 9 Surabaya

Berdasarkan temuan penelitian menunjukkan bahwa: (a) Perencanaan kurikulum berbasis entrepreneurship dilatarbelakangi oleh pemikiran yang menilai entrepreneurship mampu meningkatkan daya kreatifitas peserta didik. SMA Muhammadiyah 9 Surabaya sebagai lembaga pendidikan ingin mengembangkan pola pikir entrepreneur pada siswanya menuju era pasar global, ingin menjadikan peserta didiknya agar bisa mandiri (b) Perencanaan dilakukan dengan membuat struktur kurikulum mulai dari latar belakangnya, tujuan kurikulum, standar kompetensi, dan kompetensi dasar yang akan berkaitan langsung pada proses pembelajaran. (c) Dilakukan oleh pihak sekolah sendiri dengan melibatkan tim manajemen sekolah, perwakilan guru, serta turut diundang pula komite sekolah, ada juga bapak dan ibu majelis Dikadasmen PCM cabang Wiyung. (d) Dasar filosofis perencanaan kurikulum berdasarkan agama kita ingin meneladani tindakan nabi Muhammad SAW dalam berwirausaha dan berdasarkan tujuan pendidikan maka kita jadikan perencanaan sebagai langkah awal strategis untuk menentukan langkah selanjutnya dalam rangka kemajuan pendidikan. (e) Perencanaan kurikulum belum diikuti dengan perencanaan konten atau materi dalam kurikulum, dimana penerapan konten sementara masih bersifat umum dan lebih dimanifestasikan melalui program-program pendukung. (f) Tindak lanjut perencanaan kurikulum masih sangat sederhana dengan hanya membuat konsep hasil perencanaan sebelumnya yang masih berupa struktur kurikulum. Salah satu diantaranya dengan menentukan tujuan. Setelah itu menentukan standar kompetensi dan kompetensi dasar yang menguraikan masing-masing standar kompetensi.

$\begin{array}{clr}\text { Menurut } & \text { temuan } & \text { diatas dapat } \\ \text { diketahui } & \text { alasan } & \text { pemilihan }\end{array}$

entrepreneurship sebagai basis dalam proses pembelajaran di SMA Muhammadiyah 9 Surabaya sekaligus perencanaan penyusunan kurikulum yang mendukungnya sesuai dengan definisi perencanaan kurikulum menurut pendapat Hamalik (2010:153) bahwa, perencanaan kurikulum adalah suatu proses sosial yang kompleks, artinya banyak dipengaruhi dari beberapa faktor intern maupun ekstern yang menuntut berbagai jenis dan tingkat pembuat keputusan. Kebutuhan untuk mendiskusikan dan mengkoordinasikan proses menghendaki penggunaan model-model untuk menyajikan aspek-aspek kunci yang dianggap lebih berpengaruh pada luaran proses pendidikan kendatipun penyajian tersebut pada gilirannya harus menyederhanakan banyak aspek dan mungkin mengabaikan beberapa aspek lainnya.

Berdasarkan itu SMA Muhammadiyah 9 Surabaya memilih aspek kunci entrepreneurship yang dimasukkan pada perencanaan kurikulumnya karena dinilai lebih berpengaruh pada luaran proses pendidikan. Sebagai aspek kunci pengembangan keunggulan sekolah diharapakan seluruh warga sekolah terutama kepala sekolah sebagai manajer untuk memahami prinsip kewirausahaan, kemudian menerapkan dalam pengelolaan sekolah. Mulyasa (2006:2013) menyebutkan bahwa, "wirausaha adalah orang yang dapat meningkatkan nilai tambah terhadap sumber, tenaga kerja, alat, bahan, dan aset lain dan orang yang memperkenalkan perubahan, inovasi, dan cara-cara baru". Berwirausaha di sekolah berarti memadukan kepribadian, peluang, keuangan, dan sumber daya yang ada di lingkungan sekolah guna mengambil keuntungan. Kepribadian ini mencakup pengetahuan, ketrampilan sikap, dan perilaku. 
Selanjutnya proses perencanaan kurikulum berbasis entrepreneurship yang dilakukan dilokasi penelitian masih sangat sederhana bila dilihat dari pendapat Susilo (2008:155) yang menyatakan bahwa, tugas sekolah dalam perencanaan kurikulum adalah memahami standar kompetensi dan silabus yang berlaku secara nasional dan lokal yang sudah dikembangkan oleh Depdiknas dan Dinas Kabupaten, mengembangkan kurikulum sesuai dengan kondisi siswa dan kebutuhan masyarakat sekitar sekolah, mengembangkan materi ajar, serta membuat standar kompetensi, kompetensi inti, dan instrumen penelitian sebagai bentuk model pembelajaran. Berdasarkan itu harusnya sekolah mampu untuk membenahi perencanaan kurikulumnya dengan mengembangkan materi ajar yang sesuai dengan basis sekolah dan relevan pada perkembangan pendidikan serta mengembangkan model pembelajaran yang juga sesuai dengan basis sekolah.

Berdasarkan pemaparan diatas menurut pendapat peneliti bahwa perencanaan kurikulum yang dilakukan di SMA Muhammadiyah 9 Surabaya harus lebih variatif dan dilakukan dengan melihat aspek- aspek konten materi sekaligus pengembangan model pembelajaran yang dinamis. Entrepreneurship memang menjadi aspek pengembangan kurikulum di SMA Muhammadiyah 9 Surabaya dengan mengembangkan kemandirian peserta didik namun sekolah juga tidak boleh meninggalkan prinsip dasar pendidikan dengan mengajarkan nilai-nilai luhur lain seperti kejujuran, kerukunan, gotong royong dll. Itu semua sebagai wujud proses penciptaan keluaran pendidikan yang berkompeten, berbudaya, dan bermoral sesuai ajaran agama.

2. Pelaksanaan

Kurikulum

Berbasis Entrepreneurship di SMA Muhammadiyah 9 Surabaya
Berdasarkan temuan penelitian menunjukkan bahwa: (a) Pelaksanaan kurikulum berbasis entrepreneurship dilakukan dengan mengintegrasikan entrepreneurship pada seluruh mata pelajaran, bahkan ada beberapa mata pelajaran yang diharuskan untuk menghasilkan produk sebagai wujud capaian hasil belajarnya. Kurikulumnya mempunyai pengaturan yang berjenjang. (b) Kesiapan guru dalam menjalankan kurikulum berbasis entrepreneurship di SMA Muhammadiyah 9 Surabaya perlu sedikit dipaksakan untuk memaksimalkan kemampuannya, semua tenaga pendidik masih sama-sama belajar terkait entrepreneurship. (c) Mempunyai beberapa program unggulan diantaranya dengan memberi muatan $40 \%$ dari kurikulumnya yang berbasis entrepreneurship, workshop atau seminar entrepreneurship, pameran produk entrepreneur, on the job training (OJT) atau magang, pendidikan luar kelas (kunjungan industri). (d) Selama ini entrepreneurship dinilai sangat berkontribusi dalam mendukung pengembangan proses pembelajaran terutama dalam membentuk sifat kemandirian pada peserta didik. (e) Program pendukung yang dibuat sekolah telah mampu menumbuhkan jiwa entrepreneur peserta didik ditandai dengan adanya beberapa lulusan yang terus mengembangkan bisnisnya. (f) Pelaksanaan kurikulum berbasis entrepreneurship masih terdapat kelemahan diantaranya kurangnya fasilitas yang memadai, tenaga pendidik khusus entrepreneurship yang masih terbatas, dan kurangnya inovasi dalam pengembangan pelaksanaan kurikulumnya. (g) Kurikulum berbasis entrepreneurship di SMA Muhammadiyah 9 Surabaya diharapkan agar dapat membantu mengaktualisasikan diri peserta didik dalam perilaku wirausaha. 
Pelaksanaan kurikulum berbasis entrepreneurship yang ada di SMA Muhammadiyah 9 Surabaya perlu inovatif dan persiapan dalam implementasinya. Harusnya pelaksanaan kurikulum perlu dikembangkan berdasarkan pendapat Rusman (2009:75) bahwa, ada beberapa hal yang berpengaruh dalam melaksanakan kurikulum yang telah didesain diantaranya ada kualitas/kemampuan guru dalam memahami esensi dari tujuan yang ingin dicapai kurikulum, artinya semua guru harus paham tentang entrepreneurship dan penerapannya pada proses pembelajaran, kemampuan untuk menjabarkan tujuan kurikulum yang masih bersifat umum menjadi tujuan yang lebih spesifik, kemampuan untuk menerjemahkan tujuan khusus pada kegiatan pembelajaran. Konsep atau aplikasi konsep perlu diterjemahkan ke dalam aktivitas belajar, metode pembelajaran atau mengembangkan kemampuan menerapkan konsep. Kedua, model implementasi kurikulum. Dimana SMA Muhammadiyah 9 Surabaya melaksanakan kurikulum berbasis entrepreneurship secara konvensional dan kurang variatif dengan hanya mengintegrasikan muatannya pada seluruh mata pelajaran.

Sementara menurut Hamalik (2010:185-186) menyatakan, "pelaksanaan kurikulum dibagi menjadi dua tingkatan yaitu pelaksanaan kurikulum tingkat sekolah dan tingkat kelas". Hal itu sesuai dengan temuan penelitian bahwasannya pelaksanaan kurikulum berbasis entrepreneurship di SMA Muhammadiyah 9 Surabaya dilaksanakan secara berjenjang sesuai tingkat pendidikan peserta didik. Selain itu pelaksanaanya didukung oleh pengaturan program pendukung yang telah terjadwal dan dilaksanakan dalam rangka pengembangan basis entrepreneurship sekolah.
Berdasarkan pelaksanaan kurikulum berbasis entrepreneurship di SMA Muhammadiyah 9 Surabaya, menurut peneliti kegiatan pelaksanaan kurikulum berbasis entrepreneurship disana perlu inovasi sehingga entrepreneurship bisa cepat ditransmisikan pada peserta didik. Pelaksanaan yang baik adalah pelaksanaan yang dilakukan sesuai rencana. Pelaksanaan kurikulum berbasis entrepreneurship ini perlu didukung seluruh warga sekolah utamanya kesiapan semua guru yang ada di SMA Muhammadiyah 9 Surabaya sesuai dengan penjabaran teori diatas yang menjelaskan bahwa dukungan seluruh elemen sekolah sangat berpengaruh pada suksesnya pelakasanaan kurikulum.

\section{Evaluasi Kurikulum Berbasis Entrepreneurship di SMA Muhammadiyah 9 Surabaya}

Berdasarkan temuan penelitian yang dilakukan menunjukkan bahwa: (a) Kegiatan evaluasi dilakukan setiap tahun ajaran baru dengan berpedoman pada sasaran mutu yang telah dibuat. Memperhatikan segi dimensi program yang didalamnya ada tujuan, isi kurikulum, dan pedoman kurikulum. Kemudian yang kedua dimensi pelaksanaan didalamnya ada input, proses, output dan dampak. (b) Melibatkan tim manajemen sekolah yang terdiri dari kepala sekolah, wakil kepala sekolah semua bidang, Kepala Urusan (KAUR) yang ada, dan bapak ibu guru dengan difasilitasi pihak yayasan. Turut hadir pula perwakilan dari majelis Dikdasmen cabang Wiyung. (c) Prinsip yang digunakan ketika proses evaluasi diantaranya, prinsip keterpaduan yaitu kecocokan antara tujuan, materi pembelajaran, dan model pembelajaran. Selain itu pada proses evaluasi sekolah juga melibatkan partisipasi aktif dari peserta didik, dan prinsip koherensi antara materi yang 
diajarkan dengan tingkat kemampuan peserta didik. (d) Pelaksanaan evaluasi terkadang diikuti dengan perumusan materi pembelajaran bila memang tidak sesuai dengan tujuan kurikulum. (e) Pembenahan metode penyajian materi tidak ikut dibahas pada kegiatan evaluasi kurikulum mengingat metode setiap guru juga berbeda sesuai gayanya masingmasing. (f) Kelemahan pelaksanaan evaluasi disebabkan jadwal kegiatan evaluasi yang masih belum jelas karena menyesuaikan dengan agenda sekolah, selain itu proses evaluasi yang dilakukan kurang memeriksa secara mendalam keterkaitan antar komponen dalam kurikulum. (g) Tujuan dari kegiatan evaluasi kurikulum ini salah satu diantaranya adalah untuk mengetahui bagaimana tingkat keberhasilan kurikulum dalam mendukung pengembangan basis entrepreneurship sekolah.

Pelaksanaan evaluasi kurikulum berbasis entrepreneurship di SMA Muhammadiyah 9 Surabaya sesuai dengan pendapat Syaodih (2010:172) bahwa evaluasi kurikulum memegang peranan penting baik dalam penentuan kebijaksanaan pendidikan pada umumnya, maupun pada pengambilan keputusan sebagai pengembangan lanjutan ataupun perbaikan dalam kurikulum, dimana biasanya proses evaluasi berpedoman pada suatu alat evaluasi untuk mencapai tujuan. Hasil-hasil evaluasi kurikulum dapat digunakan oleh para pemegang kebijaksanaan pendidikan dan para pengembang kurikulum dalam memilih dan menetapkan kebijaksanaan pengembangan sistem pendidikan dan pengembangan model kurikulum yang digunakan. Pada kurikulum berbasis entrepreneurship ini hasil evaluasi dapat digunakan oleh tim manajemen sekolah untuk memperbaiki dan mengembangkan kurikulum muatannya.

Hal tersebut didukung dengan pendapat Hamalik (2010:237) bahwa Evaluasi/penilaian kurikulum adalah proses pembuatan pertimbangan dalam rangka untuk memeriksa atau mengontrol berdasarkan seperangkat kriteria yang disepakati atau alat evaluasi dan dapat dipertanggung jawabkan untuk membuat keputusan mengenai pengembangan kurikulum. Berdasarkan beberapa ulasan menurut para ahli diatas menunjukkan hal yang sesuai dengan pelaksanaan kegiatan evaluasi kurikulum berbasis entrepreneurship di SMA Muhammadiyah 9 Surabaya yang menggunakan alat atau instrumen penilaian dengan berpedoman pada dokumen sasaran mutu sekolah. Proses evaluasi dilakukan oleh tim manajemen sekolah dan pihak-pihak yang berkepentingan dengan hasilnya biasa digunakan untuk panduan dalam memperbaiki program unggulan sekolah.

$$
\text { Menurut Rusman (2009:11) }
$$

menyatakan, pada prakteknya evaluasi memiliki hakekat yang sangat luas, siswa sering diuji untuk mengidentifikasi bidang masalah utamanya yang terkait basis pengembangan sekolah. Kurikulum dapat menjadi bidang pengujian selama pengembangan untuk memastikan ketepatan tingkatan kelas tertentu pada proses pengintegrasian muatan-muatan entrepreneurship serta berkenaan dengan serangkaian ketrampilan dan isi yang mereka rancang untuk pembelajaran. Pada hal ini sekolah perlu melakukan evaluasi untuk menilai sejauh mana tingkat relevansi kurikulum yang dikembangkan dengan keadaan nyata yang berkembang dilingkungan. Selain itu kurikulum juga perlu diukur tingkat efektifitasnya agar diketahui sejauh mana perannya dalam 
mendukung basis yang telah dipilih sekolah.

Sementara itu menurut peneliti, pelaksanaan evaluasi kurikulum berbasis entrepreneurship yang ada di SMA Muhammadiyah 9 Surabaya harus dilakukan secara formatif mengingat salah satu keberhasilan pelaksanaan kurikulum dapat diukur dari evaluasi yang telah dilakukan. Melalui evaluasi secara formatif diharapakan adanya perbaikan program yang berkelanjutan.

\section{PENUTUP}

\section{Simpulan}

1. Perencanaan kurikulum berbasis entrepreneurship dilatarbelakangi oleh pemikiran bahwa entrepreneurship mampu meningkatkan daya kreatifitas dan kemandirian peserta didik. Perencanaan kurikulum dimulai dengan membuat struktur kurikulum mulai dari latar belakangnya, tujuan kurikulum, standar kompetensi, dan kompetensi dasar dengan melibatkan semua pihak yang berkepentingan khususnya tim manajemen sekolah, perwakilan guru, serta turut diundang pula bapak dan ibu majelis Dikadasmen PCM cabang Wiyung. Dasar filosofis perencanaan kurikulum dilakukan berdasarkan agama dan tujuan pendidikan. Perencanaan kurikulum belum diikuti dengan perencanaan konten atau materi dalam kurikulum, dimana penerapan konten masih bersifat umum dan lebih dimanifestasikan melalui programprogram pendukung. Perencanaan ditindak lanjuti dengan membuat konsep hasil perencanaan sebelumnya yang masih berupa struktur kurikulum, yaitu dengan menentukan tujuan, mengkonsep standar kompetensi, dan kompetensi dasar sampai menjadi hasil akhirnya yang dibuat dalam bentuk dokumen.

2. Pelaksanaan kurikulum dilakukan dengan mengintegrasikan entrepreneurship pada seluruh mata pelajaran dengan beberapa ada yang menghasilkan produk sebagai wujud capaian hasil belajarnya. Kurikulumnya mempunyai pengaturan berjenjang. Kesiapan guru dalam menjalankan kurikulum perlu sedikit dipaksakan untuk memaksimalkan kemampuannya, semua tenaga pendidik masih sama- sama belajar terkait entrepreneurship. program unggulan diantaranya dengan memberi muatan $40 \%$ dari kurikulumnya yang berbasis entrepreneurship, workshop atau seminar entrepreneurship, pameran produk entrepreneur, on the job training (OJT), pendidikan luar kelas (kunjungan industri). Selama ini entrepreneurship dinilai sangat berkontribusi dalam mendukung pengembangan proses pembelajaran terutama dalam membentuk sifat kemandirian peserta didik. Program pendukung yang dibuat sekolah telah mampu menumbuhkan jiwa entrepreneur peserta didik ditandai dengan adanya beberapa lulusan yang terus mengembangkan bisnisnya. Pelaksanaannya masih terdapat kelemahan diantaranya kurangnya fasilitas yang memadai, tenaga pendidik khusus entrepreneurship yang masih terbatas, dan kurangnya inovasi dalam pengembangan pelaksanaan. Kurikulum berbasis entrepreneurship diharapkan agar dapat membantu mengaktualisasikan diri peserta didik dalam perilaku wirausaha.

3. Kegiatan evaluasi biasnya dilakukan setiap tahun ajaran baru dengan berpedoman pada sasaran mutu. Memperhatikan segi dimensi program dan dimensi pelaksanaan. Melibatkan tim manajemen sekolah yang terdiri dari kepala sekolah, wakil kepala sekolah semua bidang, Kepala Urusan (KAUR) yang ada, dan bapak ibu guru serta turut hadir perwakilan dari majelis Dikdasmen cabang Wiyung. Menggunakan prinsip keterpaduan yaitu kecocokan antara tujuan, materi pembelajaran, dan model 
pembelajaran. Pelaksanaan evaluasi kurikulum terkadang diikuti dengan perumusan materi pembelajaran bila memang tidak sesuai dengan tujuan kurikulum, pembenahan metode penyajian materi tidak ikut dibahas pada kegiatan evaluasi kurikulum. Kelemahan pelaksanaan evaluasi disebabkan karena kurang memeriksa secara mendalam keterkaitan antar komponen dalam kurikulum. Proses evaluasi melibatkan partisipasi aktif peserta didik, prinsip koherensi antara materi yang diajarkan dengan tingkat kemampuan peserta didik dan bertujuan untuk mengetahui bagaimana tingkat keberhasilan kurikulum berbasis entrepreneurship.

\section{Saran}

Saran-saran yang dapat diberikan penulis berdasarkan temuan penelitian dan pembahasan dari hasil penelitian yaitu ditujukan kepada:

1. Kepala SMA Muhammadiyah 9 Surabaya Kemampuan manajerial yang baik kepala SMA Muhammadiyah 9 Surabaya diharapkan untuk terus dipertahankan dan selalu membimbing semua staffnya untuk terus memperluas khasanah keilmuannya.

2. Wakil kepala sekolah bidang kurikulum dan sarpras SMA Muhammadiyah 9 Surabaya

Ide kreatif sangat diharapakan terutama dalam perencanaan kurikulum maupun pelaksanaanya. Jalinan komunikasi semua warga sekolah khususnya tim manajemen sekolah juga harus ditingkatkan mengingat keberhasilan pendidikan juga keberhasilan kurikulum

3. Kepala Urusan entrepreneurship SMA Muhammadiyah 9 Surabaya

Kepala bidang entrepreneurship ini diharapkan mampu mendukung dan membantu peningkatan wawasan guru lain tentang entrepreneurship dalam rangka pencapaian tujuan sekolah sesuai basis entrepreneurship yang dikembangkan.

4. Guru SMA Muhammadiyah 9 Surabaya
Peningkatan kemampuan pedagogi maupun professional guru selalu dikembangkan mengingat guru sebagai implementator kurikulum langsung pada peserta didik, sehingga keberhasilan pelaksanaan kurikulum tentunya sangat didukung oleh kemampuan seorang implementatornya.

5. Peneliti lain

Semoga penelitian yang telah dilakukan ini bisa menjadi referensi dan informasi serta pengembangan yang lebih baik lagi dalam melakukan penelitian dibidang yang sama terkait manajemen kurikulum berbasis entrepreneurship.

\section{DAFTAR PUSTAKA}

Afidah, Mutimatul. 2013. Manajemen Kidspreneur Center (pusat pembinaan kewirausahaan) dalam Membentuk Jiwa Entrepreneurship Anak Yatim di Yayasan Al-Madinah Surabaya. Skripsi. Tidak Diterbitkan. Surabaya: Universitas Islam Negeri Surabaya

Alma, Buchari. 2009. Pengantar Bisnis. Bandung: Alfabeta.

Arikunto, S. 2006. Prosedur Penelitian (Suatu Pendekatan Praktek) Edisi Revisi 6. Jakarta: Rineka Cipta, cet. 13.

Arikunto, Suharsimi dan Yuliana, Lia. 2008. Manajemen Pendidikan. Yogyakarta: Aditya Media

Badan Pusat Statistik. 2015. Februari 2015, Tingkat Pengangguran Terbuka (TPT) sebesar 5,81 Persen [Online]. (www.bps.go.id, diakses tanggal 28 Oktober 2015 Pukul 20.00 WIB).

Bafadhal, Ibrahim. 2006. Dasar-Dasar Manajemen \& Supervisi Taman KanakKanak. Jakarta: Bumi Akasara 
Djam'an, Satori. 2000. Sasaran Pembangunan Pendidikan: Analisis Stakeholder Pembangunan Pendidikan dan Kebudayaan. Jakarta: Biro Perencanaan Sekretarian Jendral

Fattah, Nanang. 2001. Landasan Manajemen Pendidikan. Bandung: PT. Remaja Rosdakarya

Fattah, Nanang. 2008. Landasan Manajemen Pendidikan. Bandung: PT. Remaja Rosdakarya

Frinces, Z. Heflin. 2011. Be An Entrepreneur (Jadilah Seorang Wirausaha) Kajian Strategis Pengembangan Kewirausahaan. Yogyakarta: Graha Ilmu.

Hamalik, Oemar. 1993. Evaluasi Kurikulum. Bandung: PT. Remaja Rosdakarya

Hamalik, Oemar. 2006. Manajemen Pengembangan

Kurikulum. Bandung: PT. Remaja Rosdakarya

Hamalik, Oemar. 2008. Manajemen Pengembangan

Kurikulum. Bandung: PT. Remaja Rosdakarya

Hamalik, Oemar. 2010. Manajemen PengembanganKurikulum. Bandung: PT. Remaja Rosdakarya

Hasan, Hamid. 2009. Evaluasi Kurikulum. Bandung: PT Remaja Rosdakarya

Indonesia, Undang-Undang Dasar 1945

Indonesia, Undang-Undang Republik Indonesia nomor 20 tahun 2003 tentang Sistem Pendidikan Nasional

Indonesia, Undang-Undang Nomor 2 tahun 1989 tentang Sistem Pendidikan Nasional $\begin{array}{ccc}\text { Indonesia, } \quad \text { TAP } & \text { MPRS } & \text { Nomor } \\ \text { XXVI/MPRS/1966 } & \text { tentang } & \text { Agama, } \\ \text { pendidikan dan kebudayaan } & \end{array}$

Indonesia, Peraturan Pemerintah No 19 tahun 2005 tentang standar pendidikan nasional

Indonesia, Instruksi Presiden Republik Indonesia No 4 Tahun 1995

Kasmir, 2008. Kewirausahaan. Jakarta: PT. Raja Grafindo Persada

Kosasih, Ahmad. 2013. Internalisasi Nilainilai Kewirausahaan Melalui Proses Pembelajaran Untuk Menumbuhkembangkan Kemandirian Usaha. Tesis tidak diterbitkan. Jakarta: Universitas Pendidikan Indonesia. [Online]. (http://repository.upi.edu/, Diakses 16 November 2015 pukul 19.30 WIB).

Kristanto, Heru. 2009. Kewirausahaan (entrepreneuship): Pendekatan Manajemen dan Praktik. Yogyakarta: Graha Ilmu

Mardiatmo. 2008. Kewirausahaan. Surakarta: Yudisthira

Moleong, J Lexy. 2001. Metodologi Penelitian Kualitatif. Bandung: PT. Remaja Rosdakarya

Moleong, J Lexy. 2007. Metodologi Penelitian Kualitatif. Edisi Revisi. Bandung: PT. Remaja Rosdakarya

Moleong, J Lexy. 2010. Metodologi Penelitian Kualitatif. Edisi Revisi. Bandung: PT. Remaja Rosdakarya.

Moleong, J Lexy. 2012. Metodologi Penelitian Kualitatif. Edisi Revisi. Bandung: PT. Remaja Rosdakarya 
Mulyana, Deddy. 2010. Metode Penelitian Kualitatif. Bandung: PT. Remaja Rosdakarya

Mulyasa. 2004. Kurikulum Berbasis Kompetensi. Bandung: Remaja Rosdakarya

Mulyasa. 2006. Kurikulum Tingkat Satuan Pendidikan. Bandung: Remaja Rosdakarya.

Mulyasa. 2013. Manajemen dan Kepemimpinan Kepala Sekolah. Jakarta: Bumi Aksara

Nawawi, Hadari. 2005. Metode Penelitian Bidang Sosial. Yogyakarta: Gadjah Mada University Press

Purhantara, Wahyu. 2013. Analisis Kepemilikan Jiwa Kewirausahaan: Evaluasi Outcome Pendidikan Menengah DI Jawa. Jurnal Penelitian. Diterbitkan. Yogyakarta: STIE Mitra Indonesia Yogyakarta. [Online]. (journal.uny.ac.id, Diakses 09 Maret 2016 pukul 20.40 WIB).

Rasyid, Sudrajat. 2011. Kewirausahaan Santri Bimbingan Santri Mandiri. Jakarta: Citrayudah Alamanda

Rusman. 2009. Manajemen Kurikulum. Jakarta: Rajawali Pers

S. Nasution. 1995. Didaktik Asas-asas Mengajar. Jakarta: Bumi Aksara

Sasongko, Agung. 2015. Jumlah Pengusaha Indonesia Hanya 1,65 Persen [online]. (http://www.republika.co.id/berita/nasio nal/umu m/15/03/12/nl3i58 jumlahpengusaha-indonesia- hanya-165persen, diakses tanggal 17 November 2015 Pukul 19.35 WIB).
Sugiyono. 2008. Metode Penelitian Pendidikan Kuantitatf, Kualitatif, dan $R \& D$. Bandung: Alfabeta

Sugiyono. 2010. Metode penelitian Kuantitatif Kualitatif dan R\&D. Bandung: Alfabeta

Sugiyono. 2011. Metode Penelitian Pendidikan. Bandung: Alfabeta

Sugiyono. 2013. Metode Penelitian Pendidikan Pendekatan Kuantitatf, Kualitatif, dan $R \& D$. Bandung: Alfabeta

Sugiyono. 2014. Metode penelitian Kuantitatif Kualitatif dan $R \& D$. Bandung: Alfabeta

Suhanda, Andar dan Budiningsih, Asri. 2013. Perencanaan Kurikulum DI SMP NEGERI 3 SINGKAWANG. Jurnal Penelitian. Diterbitkan. Yogyakarta: PPs Universitas Negeri Yogyakarta. [Online]. (journal.uny.ac.id/, Diakses 09 Maret 2016 pukul 20.30 WIB).

Suharyadi. 2007. Kewirausahaan Membangun Usaha Sukses Sejak Usia Dini. Jakarta: Salemba Empat

Sunyobroto, Sumardi. 1995. Metode Penelitian. Jakarta: Raja Grafindo Persada

Suryana, Yuyus dan Bayu, Kartib. 2010. Kewirausahaan. Jakarta: Prenada Media Group

Suryosubroto. 2002. Proses Belajar Mengajar di Sekolah. Jakarta: Rineka Cipta

Susilo, Joko. 2008. Kurikulum Tingkat Satuan Pendidikan. Yogyakarta: Pustaka Pelajar 
Syaodih, Nana. 2001. Pengembangan Kurikulum: Teori dan Praktek. Bandung: PT. Remaja Rosdakarya Syaodih, 2010. Pengembangan Kurikulum: Teori dan Praktek. Bandung: PT. Remaja Rosdakarya

Tim Depdiknas. 1999. Panduan Manajemen Sekolah. Jakarta: Ditjen Pendidikan Dasar dan Menengah.

Trim, Bambang. 2010. Kids on Business: Vaksin Wirausaha untuk Ananda. Jakarta: PT. Tiga Serangkai Nusantara

Winarno, Agung. 2015. Model Pendidikan Kewirausahaan Adaptasi Kurikulum
2013 bagi SMK (Diskripsi Persiapan dan Hambatan Penerapan di Sekolah). Jurnal Penelitian. Diterbitkan. Malang: Universitas Negeri Malang. [online]. (journal.um.ac.id/, Diakses 10 Maret 2016 Pukul 08.40).

Yin, Robert K. 2009. Studi Kasus: Desain dan Metode. Jakarta: Penerbit Raja Grafindo Persada

Yuniati, Ratna. 2013. Program Pengembangan Jiwa Kewirausahaan Pada Anak Usia Dini Melalui Pendekatan Active Learning. Skripsi tidak diterbitkan. Jakarta: Universitas Pendidikan Indonesia. [online]. (http://repository.upi.edu/, Diakses 16 November $2015 \quad$ Pukul 19.40 